\title{
Exploring The Potential of Dermal Fibroblast Conditioned Medium on Skin Wound Healing and Anti-Ageing
}

(Meneroka Potensi Fibroblas Derma Medium Terkondisi untuk Penyembuhan Luka Pada Kulit dan Anti-Penuaan)

\author{
SHIPLU ROY CHOWDHURY*, LIM SHAUn Jing, MUHAMMAD NOOR HAZIQ BIN ZOLKAFLI, \\ NuR’ AqILAH binti MoHd Abu Zarin, Wan Alyani binti Wan AbDUllah, Nurul Aidah binti Md MothaR, \\ MANIRA MAAROF \& NUR ATIQAH HAIZUM ABDULLAH
}

\begin{abstract}
Skin ageing is associated with a decrease in collagen and delayed wound healing. The previous study has shown that supplementation of growth factors can enhance the production of extracellular matrix (ECM) and efficiency of wound healing. This study aimed to produce a Dermal Fibroblast Conditioned Medium (DFCM) and evaluate its potential on in vitro skin wound healing and anti-ageing properties. DFCM were obtained by culturing confluent human dermal fibroblasts $(\mathrm{n}=3)$ in keratinocyte-specific medium (DFCM-KM), fibroblast-specific medium (DFCM-FM) and fibroblast-specific medium with growth supplements (DFCM-GM). Protein concentration was determined by Bicinchoninic Acid (BCA) assay. To evaluate the wound healing and anti-ageing properties, human dermal fibroblasts were supplemented with three different DFCM. Fibroblasts cultured with F12:DMEM+10\% FBS was used as a control. The growth rate of fibroblasts was evaluated by culturing cells until day 4. Migration rate was evaluated at $12 \mathrm{~h}$ after seeding. In vitro healing rate was evaluated via scratch assay. Anti-ageing potential of DFCM was evaluated via RT Profiler PCR Array. Concentration of total protein was found to be significantly higher in DFCM-GM $(2914.79 \pm 150.67 \mathrm{mg} / \mathrm{mL})$ compared to DFCM-KM and DFCM-FM. Out of the tested 12 anti-ageing genes, fibroblasts supplemented with DFCM-GM demonstrated a significantly higher expression of WRN compared to other conditions. In conclusion, DFCM-GM contains more proteins and found superior in modulating wound healing and anti-ageing properties.
\end{abstract}

Keywords: Anti-ageing; conditioned medium; dermal fibroblast conditioned medium; fibroblasts; wound healing

\section{ABSTRAK}

Penuaan kulit dikaitkan dengan pengurangan kolagen dan penyembuhan luka yang lambat. Kajian terdahulu menunjukkan bahawa penambahan faktor pertumbuhan boleh meningkatkan penghasilan matriks ekstrasel (ECM) serta keberkesanan proses penyembuhan luka. Kajian ini bertujuan untuk menghasilkan medium terkondisi daripada fibroblas (DFCM) serta menilai kesannya terhadap proses penyembuhan luka dan anti-penuaan. DFCM diperoleh dengan mengkultur sel fibroblas derma manusia $(\mathrm{n}=3$ ) di dalam medium khusus keratinosit (DFCM-KM), medium khusus fibroblas (DFCM-FM) dan medium khusus fibroblas dengan penambahan faktor pertumbuhan (DFCM-GM). Kepekatan protein ditentukan dengan menggunakan asai acid Bicinchoninic (BCA). Untuk menilai proses penyembuhan luka dan anti-penuaan, kultur fibroblas ditambah dengan tiga DFCM yang berbeza. Fibroblas yang dikultur di dalam F12: DMEM + 10\% FBS digunakan sebagai kumpulan kawalan. Kadar pertumbuhan fibroblas dinilai melalui pengkulturan sel sehingga hari ke-4 manakala kadar migrasi dinilai bermula dari 12 jam selepas pengkulturan. Kadar penyembuhan luka secara in vitro dinilai menggunakan teknik pencalaran. Potensi anti-penuaan DFCM dinilai melalui RT2 Profiler PCR Array. Kepekatan protein DFCM-GM (2914.79 $\pm 150.67 \mu \mathrm{g} / \mathrm{mL}$ ) didapati jauh lebih tinggi berbanding dengan DFCM-KM dan DFCM-FM. Analisis pengekspresan 12 gen anti-penuaan menunjukkan bahawa ekspresi WRN pada fibroblas yang ditambah dengan DFCM-GM adalah jauh lebih tinggi berbanding kumpulan yang lain. Kesimpulannya, DFCM-GM mengandungi lebih banyak protein, boleh meningkatkan serta mengawal proses penyembuhan luka dan bersifat anti-penuaan.

Kata kunci: Anti-penuaan; fibroblas; medium terkondisi; medium terkondisi daripada fibroblas; penyembuhan luka

\section{INTRODUCTION}

Ageing is a fundamental biological process characteristic of all living organisms. Inevitably, ageing leads to a reduction in optimal function of organ systems, making the individual more prone to injuries and diseases (Stephens 2011). There are multiple causes of ageing, such as disturbances of cellular metabolism, cellular senescence, and cell apoptosis. One of the hallmarks of cellular ageing is the accumulation of damaged macromolecules such as DNA, proteins, and lipids. These subsequently modified chemically by reactive molecules, such as free radicals. The reactive molecules are generated during normal cellular metabolism, and production of these molecules increases with age (Rando \& Chang 2012). 
Skin is the largest organ in the human body and is susceptible to the ageing process due to exposure to the harsh external environment (Seifert et al. 2012). Skin ageing can be divided into intrinsic ageing or chronological ageing (with age) and extrinsic ageing or photo-ageing (due to physiological and environmental factors). Due to ageing, the homeostatic mechanism is lost gradually, and disrupt the structure and function of skin tissues (Ganceviciene et al. 2012).

In skin, dermal fibroblasts are responsible for producing growth factors and extracellular matrix (ECM). A study by Farage et al. (2013) has shown that ageing is associated with a decrease in collagen level. On the other hand, based on previous in vivo reports, fibronectin appeared to increase in tissues that are undergoing modification whether during inflammation or wound repair (Richard 1983). Studied done by Grinnell and Burgess (1981) found that fibronectin is a major component present during wound healing, and it promotes migration of fibroblasts.

Previous studies have shown that ageing causes the alteration in inflammatory response as well as cell migration, proliferation, maturation, and scar remodeling; hence having a great influence on effective healing of skin (Eaglstein 1986). Ageing altered the mechanisms of wound healing due to a decrease in cell proliferation and migration, deficits in matrix secretion, and a lack of mitogenic growth factors. Each of the cellular components (keratinocytes, fibroblasts, and endothelial cells) showed reduced proliferation and generalized changes in matrix deposition in the wounds of aged animals (Reed et al. 2003).

Although ageing is a natural phenomenon, it is believed that it could be delayed or prevented by certain approaches. Recently, researcher is investigating the potential of using cell secreted factors, also known as conditioned medium, for skin anti-ageing properties. Jung et al . (2012) reported that supplementation of dermal fibroblasts stem/progenitor cell-derived conditioned medium improves fibroblasts senescent by restoring the expression of collagen type I and type III, reduce the expression of MMP-1. Another report by Kim et al. (2007) shows that conditioned medium from adipose-derived mesenchymal stem cells was a potent antioxidant and demonstrated a protective effect on dermal fibroblasts. Altogether results suggest that conditioned medium from different cell source have tremendous potential as antiageing products. Thus, extensive research is required to explore its true potential and understand its mode of action.

Previous study demonstrated that skin cells in the tissue engineered constructs secretes wound healing mediators containing cytokines, chemokines and growth factors (Manira et al. 2018). In our previous study, a method was established to collect serum-free conditioned medium from dermal fibroblasts (namely DFCM) and shown to improve the attachment and expansion of keratinocytes (Chowdhury et al. 2012). Mass spectrometry analysis of DFCM demonstrated the presence of various factors including ECM, growth factors, chemokines and cytokines (Manira et al. 2018). These factors are known to involve in the regeneration of skin cells. However, production of these factors by dermal fibroblasts varied based on the composition of the basal medium. The previous study by Manira et al. (2014) demonstrated that dermal fibroblasts cultured with keratinocyte-specific culture medium (KM) containing a mixture of growth supplement (basic fibroblast growth factor (bFGF), epidermal growth factor (EGF) and insulin) resulted in the production of the higher number of proteins compared to that with serum-free fibroblast-specific culture medium (FM). Subsequently, it was shown that supplementation of CM of keratinocytespecific culture medium supports keratinocyte attachment and proliferation, while CM of fibroblast-specific medium improves migration during healing. It was previously reported that EGF, bFGF, and insulin, either alone or in combination, enhance the production of ECM. Hence, the production of $\mathrm{CM}$ using FM containing EGF, bFGF, and insulin could facilitate both proliferation and migration of cells during wound healing. Thus, in this study, we aimed to produce the DFCM by supplementing combination of EGF, bFGF, and insulin in serum-free fibroblast-specific culture medium and compare its potential on in vitro skin wound healing and anti-ageing properties with CM prepared using FM and KM.

\section{MATERIALS AND METHODS}

The experiment was conducted at Tissue Engineering Centre, Faculty of Medicine, UKM. This research was approved by Universiti Kebangsaan Malaysia Research and Ethics Committee (UKMREC) with approval code of FF-2016-098.

\section{CELL CULTURE}

Human dermal fibroblasts (HDFs) were isolated from the excess skin tissues of consented patients undergoing abdominoplasty. Tissue samples were processed and cryopreserved as described elsewhere (Seet et al. 2012). Cryopreserved HDFs were used in this study. After removal from cryotank, the cells were thawed in $37^{\circ} \mathrm{C}$ water bath. Then, cells were mixed with F12: DMEM (1:1, Sigma, USA) with $10 \%$ foetal bovine serum (PAA Laboratories, Austria) denoted as FD. Cells were seeded on a $75 \mathrm{~cm}^{2}$ T-flask and incubated at $37^{\circ} \mathrm{C}$ with $5 \% \mathrm{CO}_{2}$ atmosphere. Waste medium was discarded every 2-3 days with fresh medium until the cells reached approximately $80 \%$ confluence. Cells were then washed by Dulbecco's phosphate-buffered saline (DPBS; Thermo Fisher, USA) and treated with Trypsin-EDTA (Gibco, USA) for $5 \mathrm{~min}$ at $37^{\circ} \mathrm{C}$ to detach cells from culture surface. The cells suspension was then centrifuged and resuspended in fresh medium and seeded in new culture flask for next passage. Cells were cultured until passage 3 for the collection of conditioned medium and until passage 10 to prepare in vitro ageing model. 


\section{COLLECTION OF CONDITIONED MEDIUM}

DFCM were collected using 3 different basal media, namely: Keratinocyte-specific culture medium with growth supplement (KM); Fibroblast-specific serum-free culture medium (FM); and Fibroblast-specific serum-free culture medium with growth supplements (GM). The growth supplements, human keratinocytes growth supplements (HKGS; Gibco, USA) contains a mixture of bFGF, EGF and insulin. A total of $3 \mathrm{HDFs}$ samples $(\mathrm{N}=3)$ at $\mathrm{P} 3$ were used to prepare DFCM with 3 different basal media. Once reaching a confluence of $100 \%$, the waste medium from HDFs were removed completely, and supplemented with the 3 different basal media separately. After incubating the cells for 3 days, the basal media were collected as DFCM's and labeled as DFCM-KM, DFCM-FM, and DFCM-GM. The DFCM were then centrifuged using 3KD cut-off filter (Millipore, USA) followed by dialysis using $1 \mathrm{KD}$ cut-off dialysis bag to concentrate.

\section{PROTEIN QUANTIFICATION}

Estimation of protein concentration in the DFCM was performed using a bicinchoninic acid (BCA) protein assay kit according to manufacturer protocol (Sigma). $\mathrm{BCA}$ working reagent was prepared by mixing 50 parts of $\mathrm{BCA}$ reagent $\mathrm{A}$ with 1 parts of $\mathrm{BCA}$ reagent $\mathrm{B}$ containing Copper Sulfate. DFCMs were diluted (10x) with distilled water and transferred into a 96-well plate. Bovine serum albumin was used as a standard. Subsequently, BCA working reagent was added into each well and incubated at $60^{\circ} \mathrm{C}$ for $15 \mathrm{~min}$. The absorbance of the solution was measured at $562 \mathrm{~nm}$ and read within $10 \mathrm{~min}$. The analysis was done using 3 biological replicates and 3 technical replicates.

\section{SODIUM DODECYL SULFATE POLYACRYLAMIDE GEL ELECTROPHORESIS (SDS-PAGE)}

Protein profile of DFCM was observed in gel electrophoresis according to its molecular weight. Sodium dodecyl sulfate polyacrylamide gel electrophoresis (SDS-PAGE) was performed as described by Laemmli (1970). Proteins $(20 \mu \mathrm{g})$ from each DFCM were diluted in protein loading $\left(1: 5 \mathrm{v} / \mathrm{v}\right.$ with Transgen ${ }^{\circledR} 6 \mathrm{X}$ Protein Loading Buffer) and heated for five minutes at $95^{\circ} \mathrm{C}$. The protein ladder with a molecular weight of 10 to $260 \mathrm{kDa}$ (Spectra ${ }^{\mathrm{TM}}$ Multicolor Broad Range Protein Ladder) and the conditioned medium was loaded in the loading lanes. The electrophoresis was performed in Tris-Glycine gel on constant voltage; $4 \%$ stacking gel on $80 \mathrm{~V}$ and $8 \%$ separating gel on $180 \mathrm{~V}$. After the electrophoresis completed, proteins were fixed in the gel by immersing in fixing solution $(40 \%(\mathrm{v} / \mathrm{v})$ acetic acid glacial, $10 \%(\mathrm{v} / \mathrm{v})$ ethanol) for overnight. The gel was silver-stained using the protocol described by Heukeshoven and Dernick (1988), where the gel was sensitized for $40 \mathrm{~min}$ and developed for $8 \mathrm{~min}$. Gel image was captured using the LabScan software.

\section{GROWTH RATE \& MIGRATION RATE OF HDFS}

The growth rate and migration rate of HDFs (passage 10) in the presence of DFCM were evaluated following the protocol described elsewhere (Chowdhury et al. 2012). In brief, HDFS at the density of $2.5 \times 10^{3}$ cells $/ \mathrm{cm}^{2}$ were seeded into a 12-well plate supplemented with $25 \%$ of DFCM-KM, DFCM-FM, DFCM-GM in FD. Cells cultured with $100 \%$ FD was used as a control. Cells were observed in real time under confocal microscopy with automated stage (Nikon, Japan) at day 1 and 4 for $12 \mathrm{~h}$ with 20 min interval. Five images were captured from randomly selected position for each well. The growth rate of cells was evaluated by counting cells at 24 and $96 \mathrm{~h}(1)$. The migration rate was evaluated by measuring the distance travelled by cells within a period of $1 \mathrm{~h}$ (between 23 and $24 \mathrm{~h}$ after seeding) (2).

$$
\text { Growth rate }\left(\mathrm{h}^{-1}\right)=\begin{aligned}
& \text { Ln }(\text { cell concentration at } 96 \mathrm{~h} / \text { cell } \\
& \text { concentration at } 24 \mathrm{~h}) / 72 \mathrm{~h}
\end{aligned}
$$

$$
\begin{aligned}
& \text { Migration rate }(\mathrm{mm} / \mathrm{min})= \text { Distance travelled by } \\
& \text { cells }(\mathrm{mm}) / 60 \mathrm{~min}
\end{aligned}
$$

\section{SCRATCH ASSAY}

An amount of $1 \times 10^{4}$ cells $/ \mathrm{cm}^{2}$ of HDFs (passage 10) were seeded into a 12-well plate and cultured in FD until reached confluence. Then, a scratch was made by using $10 \mu \mathrm{L}$ pipette tip to create the wound. Cells were washed twice with DPBS and supplemented with 25\% of DFCM-KM, DFCM-FM, DFCM-GM in FD. Cells cultured only in FD were used as a control. Five images along the scratch line were captured for $12 \mathrm{~h}$ with $20 \mathrm{~min}$ interval, and healing rate was analysed using (3).

$$
\begin{aligned}
\text { Healing rate }\left(\mu \mathrm{m}^{2} / \mathrm{h}\right)= & (\text { Initial wound area }- \\
& \text { Final wound area }) \mu \mathrm{m}^{2} / 12 \mathrm{~h}
\end{aligned}
$$

\section{GENE EXPRESSION ANALYSIS VIA RT ${ }^{2}$ PROFILER PCR ASSAY}

The expression of 12 genes related to ageing was identified using a custom plate of human anti-ageing $\mathrm{RT}^{2}$ profiler PCR array kit (Qiagen, Germany). HDFs (passage 10) with or without DFCM supplementation were cultured for 72 h. HDFs were trypsinized, and total RNA was extracted using RNeasy Mini Kit (Qiagen). The RNA pellet was then washed with $70 \%$ ethanol and dried before reconstituted in RNAse and DNAse free distilled water. Yield and purity of the isolated RNA were determined by spectrophotometer (Infinite ${ }^{\circledR} 200$ PRO NanoQuant, Tecan) and cDNA synthesis was performed using $\mathrm{RT}^{2}$ first strand kit (Qiagen). The cDNA was then added to $\mathrm{RT}^{2}$ profiler PCR array plate, which contains selected primers that involved in anti-ageing processes (Table 1) and was run using Qiagen Rotor-Gene $\mathrm{Q}$ real-time cycler. The results were analysed using $\mathrm{RT}^{2}$ Profiler PCR Array software (Qiagen). 
TABLE 1. Anti-ageing genes

\begin{tabular}{ll}
\hline Genes & Description \\
\hline MRLP43 & Mammalian mitochondrial ribosomal proteins \\
POLRMT & DNA-directed RNA polymerase \\
ANXA5 & Annexin A5 \\
CLU & Clusterin \\
WRN & WRN Werner syndrome \\
CDKN1C & Cyclin-dependent kinase inhibitor 1C \\
COL1A1 & Collagen type I alpha 1 \\
COL3A1 & Collagen type III alpha 1 \\
EP300 & E1A binding protein p300 \\
CASP1 & Caspase 1 \\
PDCD6 & Programmed cell death protein 6 \\
GSTA1 & Glutathione S-transferase alpha 1 \\
\hline
\end{tabular}

\section{STATISTICAL ANALYSIS}

Three HDFs samples were used in this study. Experiments with DFCM and control for each sample were performed in triplicate. The results were shown as a mean \pm standard error of the mean (SEM). The comparison of mean between groups was evaluated by one-way analysis of variance (ANOVA) along with the Bonferroni post hoc multiple comparison tests. $p<0.05$ was considered significant.

\section{RESULTS}

\section{CHARACTERIZATION OF DFCM}

Figure 1(a) shows the concentration of total protein in DFCM-KM, DFCM-FM, and DFCM-GM. The concentration of protein in DFCM-GM $(2914.79 \pm 150.67 \mathrm{ug} / \mathrm{mL})$ was approximately 1.8 and 2.6 times higher than that in DFCM-KM $(1619.80 \pm 748.15 \mathrm{ug} / \mathrm{mL})$ and DFCM-FM $(1115.86 \pm 217.21 \mathrm{ug} / \mathrm{mL})$, respectively, and the value was significantly different.

The secreted proteins in DFCM-KM, DFCM-FM, and DFCM-GM from 3 different biological samples were analysed using 1-D SDS-PAGE (Figure 1(b)). As expected, there were comparatively more protein bands in DFCMGM than DFCM-KM and DFCM-FM, and this was more prominent for proteins with molecular weight of $\leq 35 \mathrm{kD}$. It was noteworthy that there was a little sample to sample variation within the DFCM.

\section{EFFECT OF PASSAGE ON FIBROBLASTS PROPERTIES}

Morphological characteristics of human dermal fibroblast at early (passage 3) and late (passage 10) passage was observed to demonstrate cellular ageing (Figure 2). HDFs at passage 3 displayed spindle shape morphology, while HDFs at passage 10 became flatten, enlarged and loss its original fibroblastic shape, indicating cellular ageing.

\section{EFFECT OF DFCM ON THE GROWTH RATE OF HDFS}

The growth rate of HDFs was evaluated by culturing HDFs (passage 10) with different DFCM along with a control a.
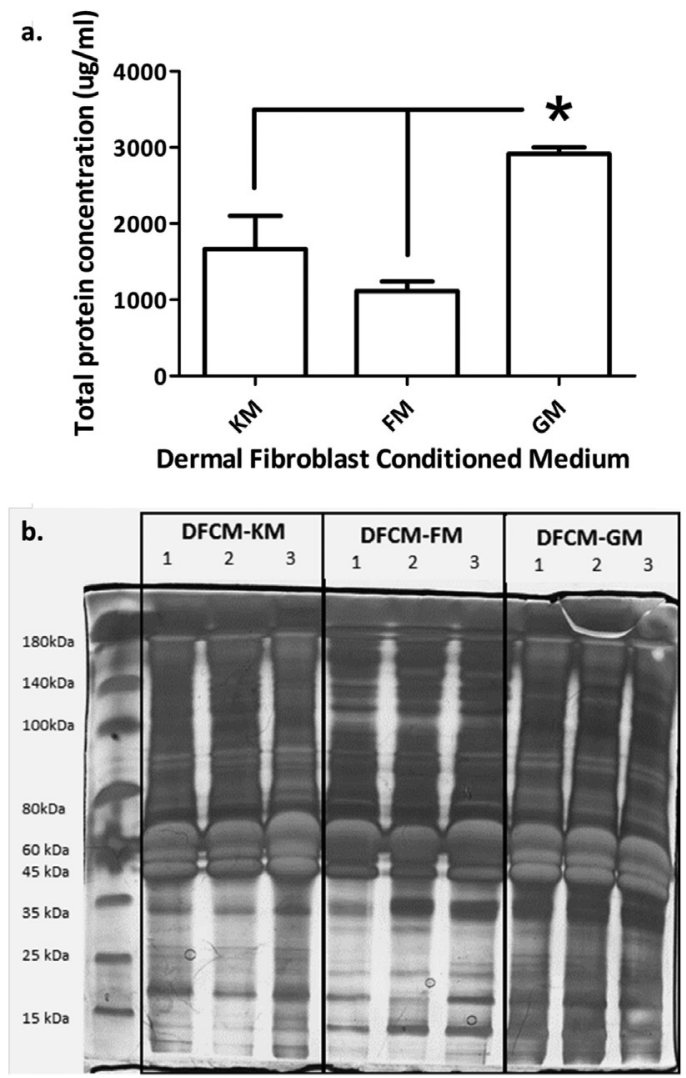

FIGURE 1. a) The concentration of total protein in DFCM-KM, DFCM-FM, and DFCM-GM measured using BCA assay and

b) Detection of protein present in different types of DFCM via 1D SDS-PAGE *indicates $\mathrm{p}<0.05$
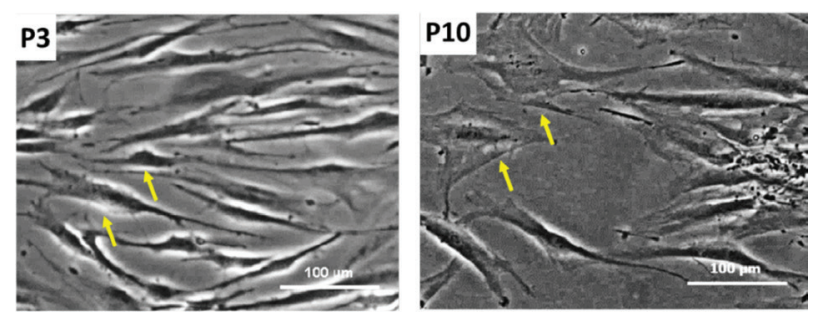

FIGURE 2. Morphological characteristics of HDFs at passage 3 and 10

for $96 \mathrm{~h}$ (Figure 3). It was found that growth rate of HDFs supplemented with DFCM-KM $\left(0.016 \mathrm{~h}^{-1}\right)$ and DFCM-GM $\left(0.015 \mathrm{~h}^{-1}\right)$ was similar to control condition $\left(0.016 \mathrm{~h}^{-1}\right)$. While supplementation of DFCM-FM shown to reduce the growth rate of HDFs $\left(0.012 \mathrm{~h}^{-1}\right)$, compared to control and other DFCM, but the value was not significantly different.

\section{EFFECT OF DFCM ON THE MIGRATION RATE OF HDFS}

The migration rate of individual HDFs (passage 10) was analyzed for $1 \mathrm{~h}$ period with $20 \mathrm{~min}$ interval cultured on conditions with or without DFCMs (Figure 4). In the culture supplemented with DFCM-FM, most of the cells 


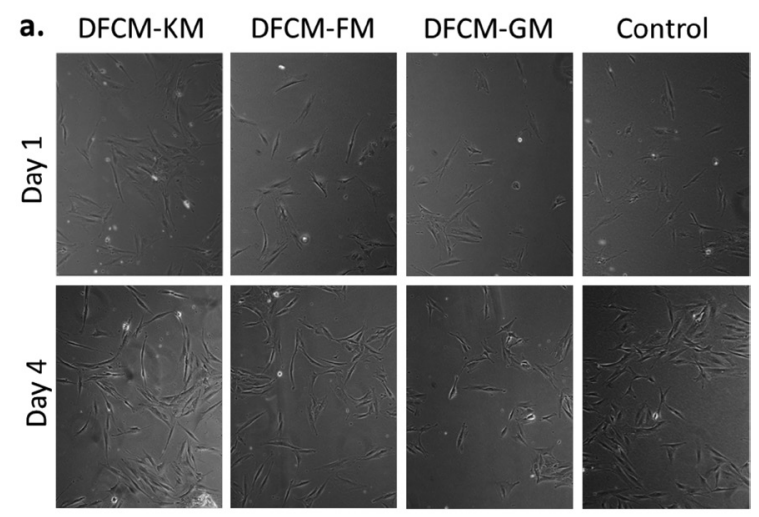

b.

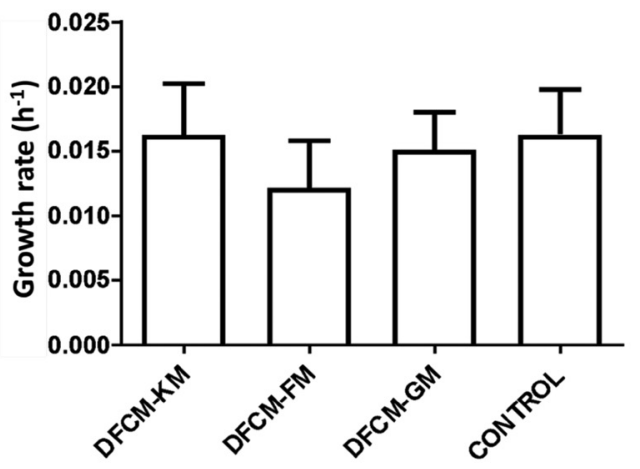

FIGURE 3. The representative images (a) and growth rate (b) of HDFs (passage 10) in the presence of DFCM. No significant difference was observed for growth rate among culture conditions

were spreading and migrating slower as compared to cells supplemented with DFCM-KM, DFCM-GM, and control. The quantitative evaluation showed that migration rate of HDFs in culture supplemented with DFCM-FM $(0.26 \pm 0.02 \mu \mathrm{m} /$ min) was significantly lower compared to other conditions. No significant difference was observed for the migration rate of HDFs on DFCM-KM, DFCM-GM, and control.

\section{EFFECT OF DFCM ON THE HEALING PROPERTIES OF HDFS}

To evaluate the wound healing efficiency of DFCM, healing rate of HDFs was evaluated via scratch assay (Figure 5). No significant difference in healing rate was observed among groups although supplementation of DFCM-KM shown to reduce the healing rate compared to other conditions.

\section{EXPRESSION OF THE ANTI-AGEING GENE}

To evaluate the anti-ageing properties of DFCM, expression of genes associated with ageing, namely MRLP43, POLRMT, ANXA5, CLU, WRN, CDKN1C, COL1A1, COL3A1, EP300, CASP1, PDCD6, and GSTA1 were measured. Out of 12 genes, the expression of WRN in HDFs was significantly higher when supplemented with DFCM-GM as compared to DFCM-KM, DFCM-FM, and control condition (Figure $6)$. On the other hand, expression of COL1A 1 in HDFs supplemented with DFCM-FM and the control condition was significantly higher as compared to DFCM-KM, but no significant difference was observed for DFCM-GM. The expression of other genes showed no significant differences for all conditions.

\section{DISCUSSION}

Conditioned medium (CM) contains numerous cytokines, chemokines, growth factors and ECM proteins. The use of CM has become attractive approach since it can be used allogenically and contain proteins that can promote cells growth, cell differentiation, and tissue repair. The secretory factors in the $\mathrm{CM}$ are involved in the intercellular communication and have a significant biological effect. Secretory proteins from mesenchymal stem cells and fibroblasts are shown to involve in promoting of wound healing properties of skin cells. However, the composition of $\mathrm{CM}$ can be varied based on the preconditioning environment. CM was shown to collected under stress condition such as exposing the cells to serum-free medium or hypoxic condition. Besides, different microenvironment including the composition of supplemented medium can affect the secretory properties of the cells. In this study, it was found that presence of growth supplement in the culture medium results in an increment of protein secretion and facilitates wound healing and anti-ageing properties of human dermal fibroblasts (HDFs).

In our previous study, collection of DFCM using serum-free keratinocyte medium (KM) containing bFGF, EGF and insulin resulted in 1.5 times increment of protein concentration than that using serum-free fibroblast 

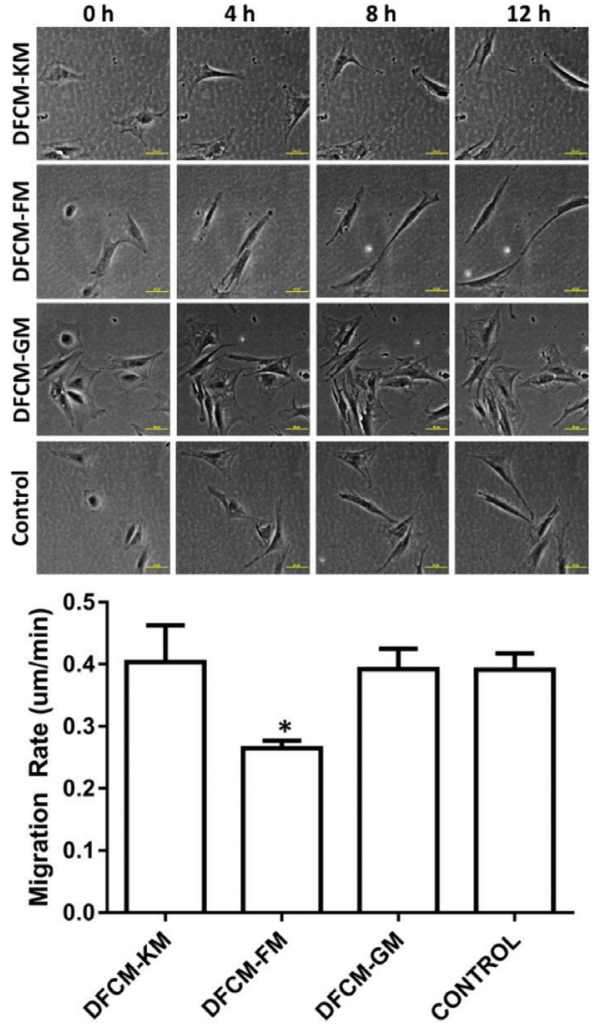

FIGURE 4. The migration rate of HDFs under different culture condition. Photomicrograph showing the cellular displacement over time. Quantitative evaluation shows the significantly lower $(p<0.05)$ migration rate of HDFs cultured with DFCM-FM compare to other conditions
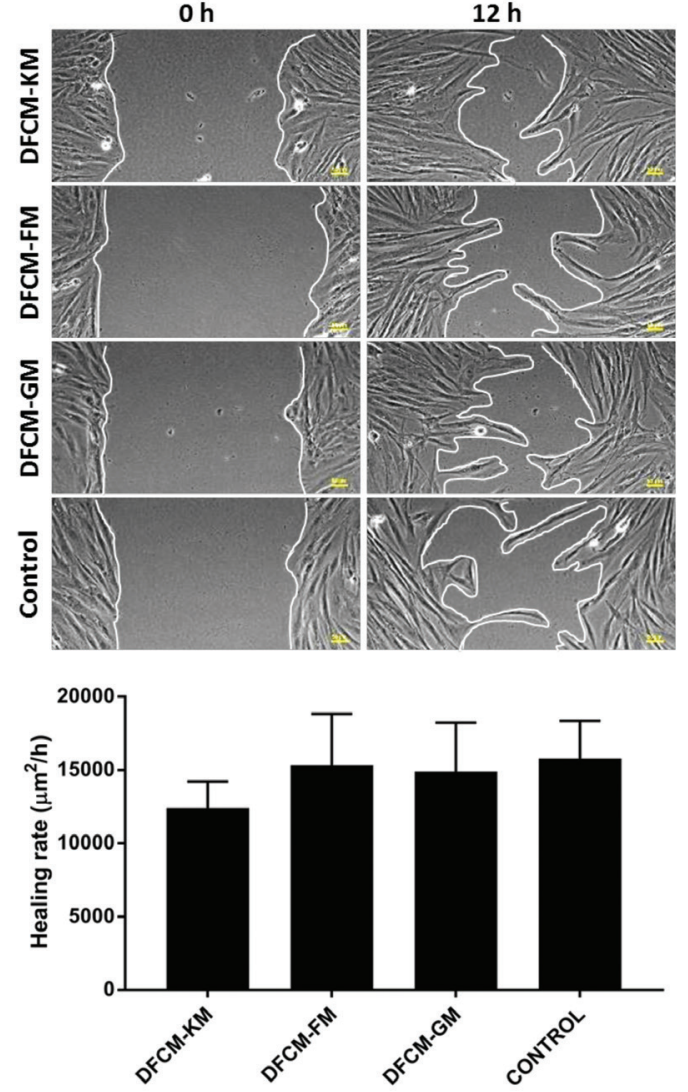

FIGURE 5. Healing rate of HDFs under different culture conditions. No significant difference in healing rate was observed among groups

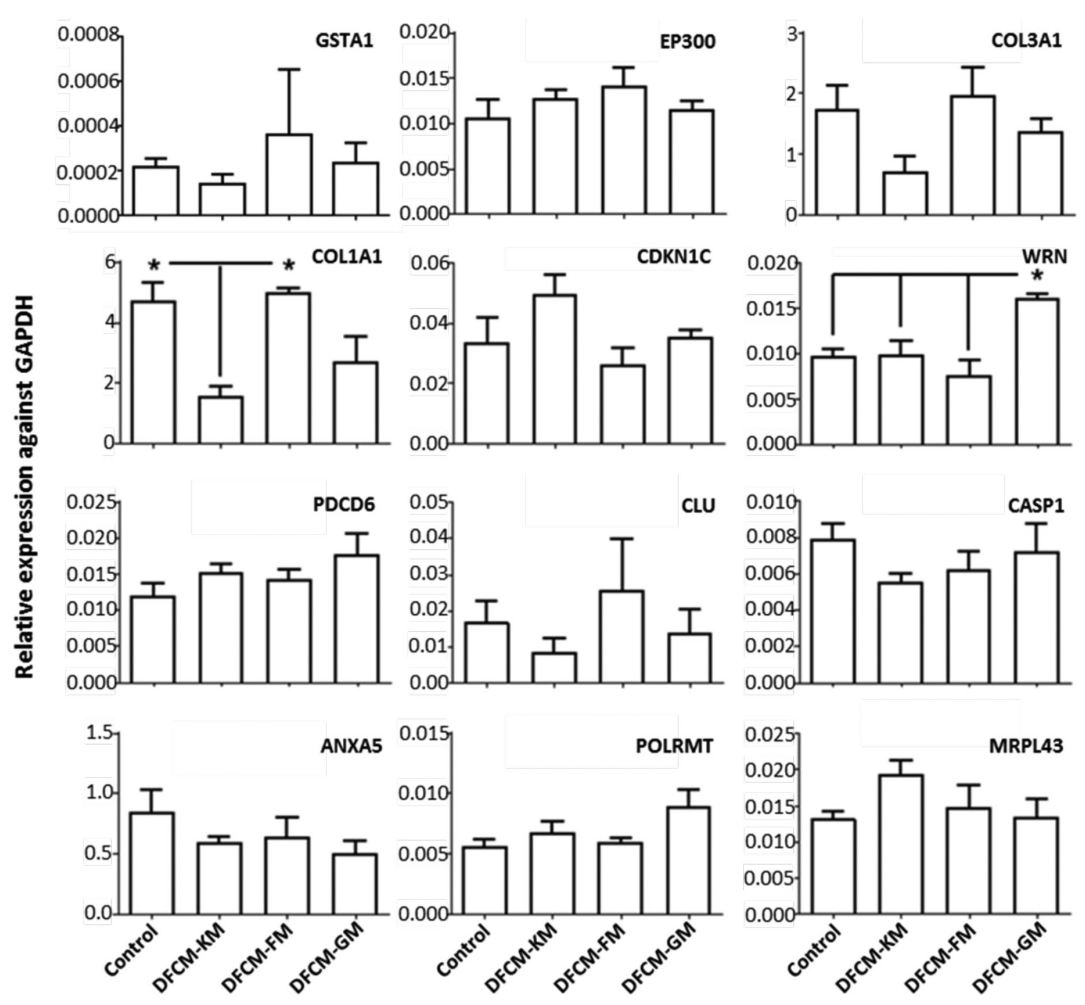

FIGURE 6. Expression of anti-ageing genes by HDFs supplemented with DFCM *indicates significant difference $(p<0.05)$ 
medium (FM) without any supplement. Analysis of the secretory proteins demonstrated that number of secretory proteins was also higher in DFCM-KM compared to that in DFCM-FM (Manira et al. 2018). However, it was found that these DFCM improves different properties of wound healing phenomena when supplemented to keratinocytes. DFCM-KM was suitable for attachment and proliferation of keratinocytes, while DFCM-FM significantly enhances the migration of cells during wound healing, which we assume due to the different composition of the DFCM. According to a study done by Xie et al. (2007), stimulation of fibroblasts by bFGF increase the expression of proteins such as fibronectin, collagen types I and III, and MMP-1, which helps to improve the wound healing process. In addition, Lee et al. (2007) reported that co-supplementation of EGF and insulin on the confluent fibroblast culture enhances the production collagen type I. Thus, it is expected that supplementing this factors to HDFs will support the secretion of proteins. In this study, DFCM-GM was prepared by adding growth supplement, i.e., bFGF, EGF, and insulin in the FM during the collection of CM from fibroblasts. The results suggested that DFCM-GM contains a significantly higher amount of proteins compared to DFCM-KM and DFCM-FM. It is also noteworthy to mention that BCA assay and 1D SDS-PAGE analysis shows minimum sample to sample variation for each DFCM. However, mass spectrometry analysis should perform for further confirmation.

Wound healing properties that includes growth, migration and healing rate of fibroblasts were studied in this research. HDFs cultured with DFCM-GM demonstrated consistent wound healing properties for all three parameters that were studied as compared to DFCM-KM and DFCM-FM, indicating that DCFM-GM provided suitable environment for HDFs to facilitate wound healing. In accordance with our previous observation for keratinocytes (Izzah et al. 2016), supplementation of DFCM-FM resulted in the reduction of growth rate and migration rate (individual cells at sub-confluence state) of HDFs. Although DFCM-FM significantly enhanced the rate of healing of keratinocytes, no difference was observed for HDFs. However, DFCM$\mathrm{GM}$, which was produced using similar basal medium as DFCM-FM with growth supplements, enhance the growth rate and migration rate at sub-confluence state than DFCMFM and demonstrate similar migration rate during healing as DFCM-FM. This result indicates that supplementation of growth supplement in the FM during the collection of $\mathrm{CM}$ facilitates the secretion of factors that is suitable for the wound healing properties of HDFs.

Besides wound healing properties, the effect of DFCM on anti-ageing properties was also investigated in this study. Total of 12 genes was selected based on their involvement in the ageing process of humans such as genomic instability and mitochondrial dysfunction, inflammatory response, apoptosis, cellular senescence, cell cycle, cytoskeleton regulators, DNA binding, oxidative stress, and transcriptional regulation (Table 1). Out of these 12 genes, WRN demonstrated a significantly higher expression in fibroblasts supplemented with DFCM-GM as compared to DFCM-KM, DFCM-FM, and control condition. A study by Lee et al. (2005) has shown that WRN is a helicase and exonuclease involved in many DNA repair and processing pathways. Kamath (2012) demonstrated that cells expressing reduced amounts of WRN had increased mutation frequencies as compared to wild-type cells. It is well known that deletion mutation of WRN gene causes Werner's syndrome, an autosomal recessive disorder characterized by premature ageing. Although its exact mechanisms remain unknown, it is one of the strongest candidates for genes influencing human ageing. Based on these observations, DFCM-GM has the potential of exhibiting an anti-ageing role in fibroblasts.

On the other hand, DFCM-FM yielded significantly higher COL1A1 as compared to DFCM-KM and control but no significant difference to DFCM-GM. COL1A1 is responsible for the production of type 1 collagen, which contributes to resisting deformation and tearing of the skin. Collagen can also regulate cell migration and proliferation and modulate gene expression. A study conducted by Varani et al. (2007) has shown that in aged skin, production of collagen was decreased. Thus, supplementation of DFCMGM to HDFs contributes to the expression of genes that act in the delaying of the ageing process.

\section{CONCLUSION}

In conclusion, supplementation of bFGF, EGF, and insulin in serum-free fibroblast medium (FM) resulted in the production of CM, i.e., DFCM-GM with a higher concentration of proteins. The resultant DFCM-GM shows a consistent effect on wound healing properties, i.e., growth rate and migration rate (individual cells and during healing) of HDFs in compared to that of DFCM-KM and DFCM-FM. Moreover, supplementation DFCM-GM shows the expression of anti-ageing genes by HDFs. Together all these results suggested that DFCM-GM could be a potential supplement for the rejuvenation of the skin.

\section{ACKNOWLEDGEMENTS}

This study was funded by the UKM Medical Centre Fundamental Fund (FF-2016-098 and FF-2015-204).

\section{REFERENCES}

Chowdhury, S.R., Aminuddin, B.S. \& Ruszymah, B.H.I. 2012 Effect of supplementation of dermal fibroblasts conditioned medium on expansion of keratinocytes through enhancing attachment. Indian Journal of Experimental Biology 50: 332-339.

Eaglstein, W.H. 1986. Wound healing and aging. Dermatologic Clinics 4(3): 481-484.

Farage, M.A., Miller, K.W., Elsner, P. \& Maibach, H.I. 2013. Characteristics of the aging skin. Advances in Wound Care 2(1): 5-10.

Ganceviciene, R., Liakou, A.I., Theodoridis, A., Makrantonaki, E. \& Zouboulis, C.C. 2012. Skin anti-aging strategies. Dermatoendocrinology 4(3): 308-319. 
Grinnell, F. \& Burgess, L. 1981. Distribution of fibronectin during wound healing in vivo. Journal of Investigative Dermatology 76(3): 181-189.

Heukeshoven, J. \& Dernick, R. 1988. Improved silver staining procedure for fast staining in PhastSystem Development Unit. I. Staining of sodium dodecyl sulfate gels. Electrophoresis 9(1): 28-32.

Jung, S., Sen, A., Rosenberg, L. \& Behie, L.A. 2012. Human mesenchymal stem cell culture: Rapid and efficient isolation and expansion in a defined serum-free medium. Journal of Tissue Engineering and Regenerative Medicine 6(5): 391403.

Kamath-Loeb, A.S., Shen, J.C., Schmitt, M.W. \& Loeb, L.A. 2012. The Werner Syndrome exonuclease facilitates DNA degradation and high-fidelity DNA polymerization by human DNA polymerase $\delta$. Journal of Biological Chemistry 287(15): 12480-12490.

Kim, W.S., Park, B.S., Sung, J.H., Yang, J.M., Park, S.B., Kwak, S.J. \& Park, J.S. 2007. Wound healing effect of adiposederived stem cells: A critical role of secretory factors on human dermal fibroblasts. Journal of Dermatological Science 48(1): 15-24.

Laemmli, U.K. 1970. Cleavage of structural proteins during the assembly of the head of bacteriophage T4. Nature 227(5259): 680-685.

Lee, D.Y., Yang, J.M. \& Park, K.H. 2007. A dermal equivalent developed from fibroblast culture alone: Effect of EGF and insulin. Wound Repair and Regeneration 15: 936-939.

Lee, J.W., Kusumoto, R., Doherty, K.M., Lin, G.X., Zeng, W., Cheng, W.H., von Kobbe, C., Brosh, R.M. Jr., Hu, J.S. \& Bohr, V.A. 2005. Modulation of Werner Syndrome protein function by a single mutation in the conserved RecQ domain. Journal of Biological Chemistry 280(47): 39627-39636.

Manira, M., Yogeswaran, L., Ruszymah, B.H.I., Aminuddin, B.S. \& Chowdhury, S.R. 2018. Proteomic analysis of human dermal fibroblast conditioned medium (DFCM). The Protein Journal 37: 589-607.

Manira, M., Law, J.X., Chowdhury, S.R., Khairul, A.K., Aminuddin, B.S. \& Ruszymah, B.H.I. 2016. Secretion of wound healing mediators by single and bi-layer skin substitutes. Cytotechnology 68(5): 1873-1884.

Manira, M., Chowdhury, S.R., Rosliza, A., Yi Ling, A., Abidah, A., Vittarino, J., Nurul Izzah, A., Aminuddin, B.S. \& Ruszymah, B.H.I. 2014. Concentration dependent effect of dermal fibroblast conditioned medium on in vitro wound healing properties of keratinocytes. Regenerative Research $3(2): 30-32$.
Nurul 'Izzah, A.G., Aminuddin, B.S., Ruszymah, B.H.I. \& Chowdhury, S.R. 2016. Calcium in dermal fibroblast conditioned medium (DFCM) enhance keratinocytes wound healing in vitro. Abstract in 6th Malaysian Tissue Engineering \& Regenerative Medicine Scientific Meeting. p. 48.

Rando, T.A. \& Chang, H.Y. 2012. Aging, rejuvenation, and epigenetic reprogramming: Resetting the aging clock. Cell 148(1-2): 46-57.

Reed, M.J., Koike, T. \& Puolakkainen, P. 2003. Wound repair in aging. In Wound Healing. Methods in Molecular Medicine ${ }^{T M}$, edited by DiPietro, L.A. \& Burns, A.L. vol 78. Totowa, NJ: Humana Press.

Richard, A.F.C. 1983. Fibronectin in the skin. The Journal of Investigative Dermatology 81(6): 475-479.

Seet, W.T., Maarof, M., Khairul Anuar, K., Chua, K.H., Ahmad Irfan, A.W., Ng, M.H., Aminuddin, B.S. \& Ruszymah, B.H.I. 2012. Shelf-life evaluation of bilayered human skin equivalent, MyDerm ${ }^{\mathrm{TM}}$. PLoS ONE 7(8): e40978.

Seifert, A.W., Monaghan, J.R., Voss, S.R. \& Maden, M. 2012. Skin regeneration in adult axolotls: A blueprint for scar-free healing in vertebrates. PloS ONE 7(4): e32875.

Stephens, P. 2011. Dysfunctional wound healing in chronic wounds. In Advanced Wound Repair Therapies, edited by David Farrar. $1^{\text {st }}$ ed. Cambridge, UK: Woodhead Publishing Limited.

Varani, J., Dame, M.K., Rittie,L., Fligiel, S.E.G., Kang, S., Fisher, G.J. \& Voorhees, J.J. 2006. Decreased collagen production in chronologically aged skin: Roles of age-dependent alteration in fibroblast function and defective mechanical stimulation. The American Journal of Pathology 168(6): 1861-1868.

Xie, J., Bian, H., Qi, S., Xu, Y., Tang, J., Li, T. \& Liu, X. 2008. Effects of basic fibroblast growth factor on the expression of extracellular matrix and matrix metalloproteinase-1 in wound healing. Clinical and Experimental Dermatology 33(2): 176-182.

Tissue Engineering Centre, Faculty of Medicine

Universiti Kebangsaan Malaysia

Jalan Yaacob Latif

56000 Cheras, Kuala Lumpur, Federal Territory

Malaysia

*Corresponding author; email: shiplu@ppukm.ukm.edu.my

Received: 17 April 2018

Accepted: 29 November 2018 